\title{
Spatial Features and Indicators of Habitation Quality in the Human Settlements of the Ialomiţa Subcarpathians
}

\author{
Monica Carmen BALTĂLUNGĂ' \\ ${ }^{1}$ Bucharest University, Faculty of Geography, "Simion Mehedinţi” Doctoral School, ROMANIA \\ E-mail: carmen_barlad41@yahoo.com \\ DOI: 10.24193/JSSP.2017.1.03
}

https://doi.org/10.24193/JSSP.2017.1.03

K e y w o r d s: land fund, agricultural/non-agricultural area, indicators, habitation, settlements

\begin{abstract}
A B S T RA C T
The geographic studies involving in various forms the human settlements need to also include quantitative and qualitative references on their spatial features. These studies also need to include aspects on habitation and the reference should be, in this case, to the norms in force or, where they do not exist, to regional, national or even international averages, depending on the situation. Thus, important landmarks are created for comparisons based on which analyses can be made in terms of the way natural conditions are reflected in the quality of life and in the way they could be profitably used in economy. The relief of the Ialomiţa Subcarpathians has been a favourable factor for the founding and development of settlements, especially along the valleys and in the depressions separated by forested hills. The first part of this study presents the land structure of and analyzes the land fund, closely related in practice to the land use. This also gives a conclusive image on the dominant economic activities. Settlement dispersion was another element for correlation, the series of values recorded being quite large by comparison to the generally unitary aspect of the relief. Later on, starting from this general image on the quality of habitation, for a precise quantification, seven indicators have been used. For five of them, a positive dynamics has been noted, confirming the development potential of the area, despite the negative demographic phenomena characterizing it at present. At the same time, this helps delimit the more or less attractive areas in this region, which could constitute the basis for diagnosis and could provide guidelines for directions of interventions by development programs where demographic and economic re-dynamization is needed.
\end{abstract}

\section{INTRODUCTION}

This study presents the manner in which the natural potential of the Ialomiţa Subcarpathians is managed from the perspective of land use and the way these aspects influence the habitation quality, as a defining element of the life quality dimensions. The Subcarpathian relief, although significantly fragmented, is characterized by accessible corridors (Fig. 1), which have favoured human settlements especially along the valleys and in the depressions (Fig. 2, Fig. 3). The valleys, both principal and secondary, with terraces and large riversides, concentrate the most numerous and largest settlements [1]. Most settlements are generally large and situated on these river terraces, thus protected from floods. The water table is close to the surface, and the soils are fertile and favourable to farming. There are also some settlements situated on less inclined slopes and hill tops, leading to the development of scattered settlements, with the houses spread out across the entire estate [2]. Both the depressions (Fieni, Pucioasa, Vulcana, Ocniţa etc.) and the hills (Bărbuleţului, Vulcanei, Ocniţei, Bezdeadului, Talei etc.) shelter settlements at altitudes ranging from 500 to $800 \mathrm{~m}$ ). In 1931, the great geographer Ion Conea said about the Subcarpathians that "they seem to have 
been created from the beginning to shelter human settlements" [3].

The settlements in the Subcarpathians, in general, and in this subunit in particular, illustrate an active adaptation to the specific physical-geographical landscape, and to all the natural elements it includes. This explains why, although the Subcarpathians cover only around $7.5 \%$ of the surface area of Romania, they are inhabited by $13 \%$ of the country's population and are occupied by $14 \%$ of the total number of human settlements.

The highest altitude for permanent human settlements in the Ialomiţa Subcarpathians is $820 \mathrm{~m}$ (Meişoare, on the Dâmboviţa - Valea Largă watershed divide).

The rural habitat in the Ialomiţa Subcarpathians "has been largely influenced by the water resources and the topoclimatic potential" [4].

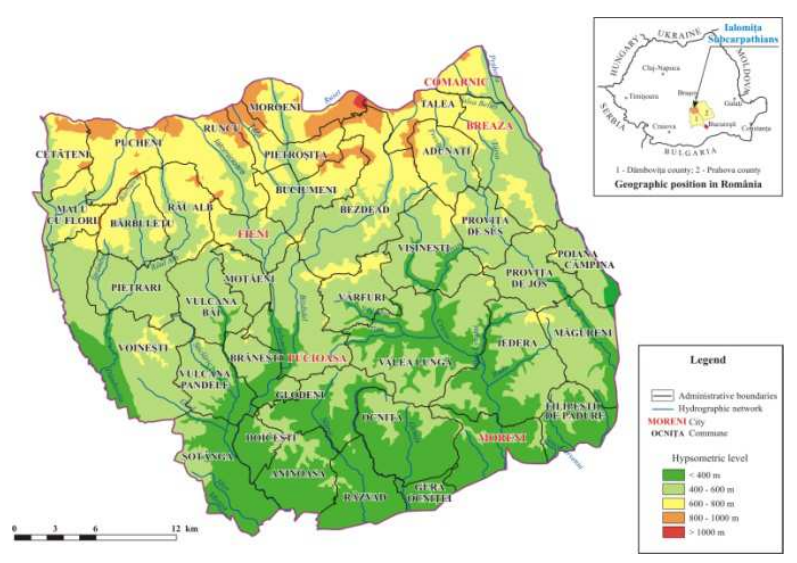

Fig. 1. Settlements distribution on relief tiers.

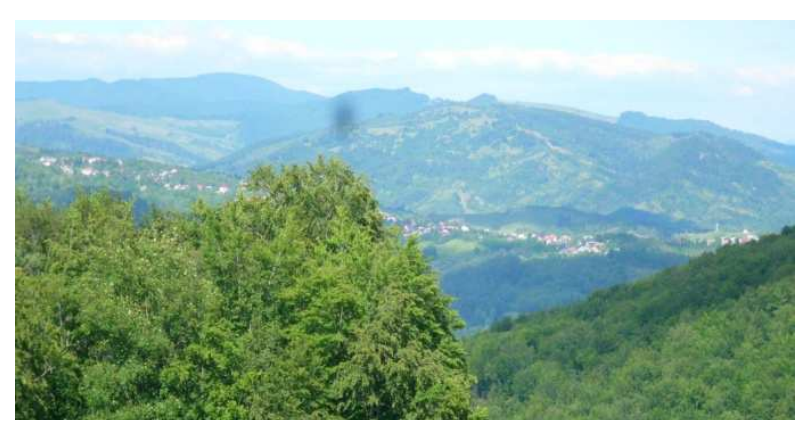

Fig. 2. Runcu Commune - general overview.

From a historical perspective, the first villages emerged in the first millennium in sheltered areas, by the mountain, on slopes or secondary valleys. In the second millennium, a village dispersion process towards the valley corridors and the main depressions began, and, gradually, villages appeared near the plain as well [5]. This move confirms the general rule which states that as the political, economic, social and military climate in a country or region improve the settlements start moving to lower elevations. At the end of the $19^{\text {th }}$ century and the beginning of the $2 \mathrm{O}^{\text {th }}$, settlements along roads, near towns or in resource exploitation areas emerged and developed. Yet, at the same time, the deforestation and overbuilding on slopes are problems causing land degradation [6].

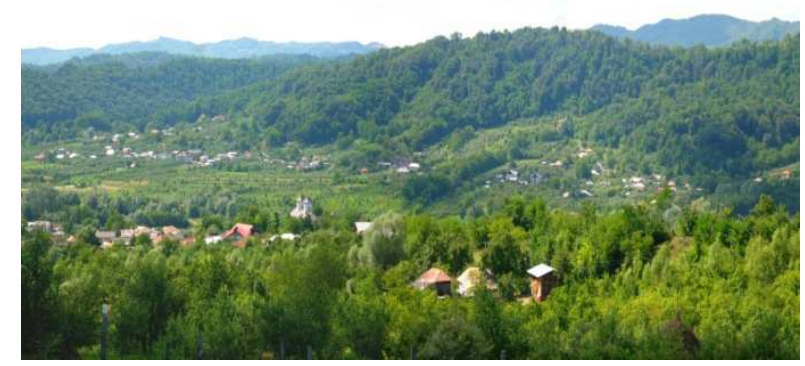

Fig. 3. Pietrari Commune - general overview.

Most towns in the Subcarpathian area emerged (in the sense that they were declared towns) during the last 150 years. Most are situated on large valley corridors and their neighbourhoods unfold on terraces or on the glacis at the basis of the slopes. They largely preserve the physiognomic, structural and textural aspects specific of rural settlements (especially the localities they include). Their emergence and evolution was related to: oil exploitation (Moreni), building materials industry (Comarnic and Fieni), and spa potential and a series of industrial activities (Breaza and Pucioasa).

Moreni was declared town on 17 September 1947 and subsequently city in 19 June 2003. Pucioasa was declared a town in the year 1929 (7 December) and a tourist resort of national importance in the year 1999. Breaza has been a town since 1956, and Fieni and Comarnic since 1968.

The largest town, by population, is Moreni City. This is also the only urban settlement in the region without any villages in administration. The other towns administer 21 villages between them, 16 of which falling within the study area: 2 Fieni, 6 Pucioasa, 6 Breaza and 2 Comarnic. It is important to mention that for Comarnic, the actual town is in the Subcarpathians of Ialomiţa along with only two of the localities it administers (Ghioşeşti and Podul Lung).

\section{THEORY AND METHODOLOGY}

This study belongs to a broader analysis of human behaviour differentiation in this area. Thus, geographically, human behaviour involves, among others, an approach of the relation between man and environment. These relations are best expressed by means of the human settlements, both from the perspective of habitation, and from that of the economic activities. Habitation quality is an integrated and very complex concept, and, integrating approaches from the viewpoint of several disciplines (geography, environment, architecture, sociology, psychology etc.), it has an interdisciplinary character. Human behaviour analysis in a territorial context supposes the significant 
contribution of geography in order to understand this relation beyond the sociological and psychological analyses of the phenomenon [7]. The spatial dimension of the human existence is essential because space gives man a feeling of belonging, mobility, experience, cognitive horizons, and emotional charge [8]. The geographic horizon features result from the great quantitative and qualitative variety of the elements composing it. "Any space has metric dimensions (...), some of them set in an a priori manner by administrative-territorial limits or other subjective delimitation caused by the need to study/analyze a certain territorial set" [9]. This also underlines the need of interdisciplinary approaches reflected in the correlation of diverse analysis methods able to answer the complexity of the settlements development problems [10]. Even since the first half of the past century it has been stated that it is almost impossible to study the natural landscape separately from the anthropogenic one - "the relation society-nature has grown so close that it is no longer possible to discern the influence of man on nature or of nature on man" [11].

Space and its features have an essential role in the first two levels of human needs (physiological and of security), situated at the base of Maslow's pyramid [12].

Social phenomena and processes are characterized by numerous quantitative and qualitative components that need to be quantified using indicators. Their definition is very important but also difficult because of their multidimensional character (economic, cultural, political psychological etc.). Practically, what is expressed is simultaneously relations among people, and between people and nature [13]. Economic indicators, generally the most used, do not always reflect well-enough the level of population satisfaction and the quality of life [14].

The period under analysis starts with 1990 and ends at present, with small variations of the extreme limits according to the availability and unity of the statistical data.

The issues approached concern three directions, all related to spatial aspects - the first two are the spatial distribution of settlements, in general, and land structure /use in their framework, while the third is habitation quality, and components of life quality at dwelling /household level. Habitation (work capacity, social relations and development activities) is conditioned by features of the built or arranged area [15]. The human habitat quality depends on the division and distribution of the internal structural elements in the human settlement [16]. Studies on life quality have grown in importance within the discipline of geography during the last decades, at the same time highlighting and delimiting the goals of the local and regional policies in this sense [17]. There are a series of definitions related to the habitation quality in the international literature [18]. For example, Uehara E. S.
(1994) views habitation quality as a multidimensional concept that can be evaluated by examining a number of physical and social features of a location and its surroundings [19]. According to Lawrence R. (1995) habitation quality, as a concept, includes ideas from different disciplines (demography, economy, ecology, politics and architecture), pursuing several objectives [20]. Castro M. E. (1999) considers that habitation quality analysis must consider the psychic, social and environmental factors defining psychic, physical and biological health, starting from the premise that habitation is the habitat capacity to meet the objective and subjective needs of a person or of the group it belongs to [21].

The statistical data used, in absolute values, come from the National Statistics Institute and from the Department of Statistics of Dâmboviţa, Prahova and Argeş counties [22], [23], [24], [25]. The ratios and the indicators used represent our own contribution and have been calculated based on these data. In tables, the settlements have been grouped by towns and communes, then by counties and in alphabetical order.

\section{RESULTS AND DISCUSSION}

The Subcarpathians of Ialomiţa, a particularly complex natural unit from a physical-geographical but also economic perspective, include a total of 137 human settlements, grouped into 5 towns and 34 communes. The area under analysis totals $1,655.63 \mathrm{~km}^{2}$. The resulting town density is 3.01 towns $/ 1,000 \mathrm{~km}^{2}$ and the village density is 7.06 villages $/ 100 \mathrm{~km}^{2}$ (here we did not include the 16 villages administered by the towns; only the towns as such). In both situations, the values are over the national average ( 1.34 for towns, and 5.45 for villages), highlighting the features of an attractive and populous area.

\subsection{Land fund structure}

In the area under analysis, the total land fund has gone through some changes since 1990, due to administrative-territorial reorganization measures. Compared to this year, three new communes emerged:

a). Pietrari - was a commune between the end of the $19^{\text {th }}$ century and 1968 , when it was abolished and became a village included in Bărbuleţu Commune. The Pietrari Commune was then recreated in the year 2004 (Law 541/2004);

b). Râul Alb - between the founding of the village (the first half of the $18^{\text {th }}$ century) and the year 1870 it was part of Bărbuleţu Commune. Then it became an independent commune until 1968, when, similarly to the situation of Pietrari Commune, it was abolished and included in Bărbuleţu Commune, as well. It was recreated in the year 2004 (Law 542/2004);

c). Vulcana-Pandele - similarly to the previous cases, it was abolished in the year 1968 - when it was included in Brăneşti Commune, and recreated in the year 2002 (Law 431/2002). The total area of the land 
fund is 165,563 ha $\left(1,655.63 \mathrm{~km}^{2}\right)$ on the level of the year 2014, out of which $45.7 \%$ is represented by agricultural areas, and $54.3 \%$ by non-agricultural areas (Table 1 \& Fig. 4).

Table 1. Land fund area (ha).

\begin{tabular}{|c|c|c|c|c|c|c|c|c|}
\hline \multirow[b]{2}{*}{ No. } & \multirow{2}{*}{$\begin{array}{c}\text { Town/ Commune } \\
\text { Year }\end{array}$} & \multicolumn{2}{|c|}{ TOTAL } & \multicolumn{3}{|c|}{ Agricultural area } & \multicolumn{2}{|c|}{ Non-agricultural area } \\
\hline & & 1990 & 2014 & 1990 & 2014 & $(\%)$ & 2014 & $(\%)$ \\
\hline 1. & Moreni & 3,514 & 3,514 & 957 & 957 & 27.2 & 2,557 & 72.8 \\
\hline 2. & Fieni & 1,831 & 1,831 & 1,062 & 1,062 & 58.0 & 769 & 42.0 \\
\hline 3. & Pucioasa & 4,009 & 4,009 & 2,151 & 2,147 & 53.5 & 1,862 & 46.5 \\
\hline 4. & Breaza & 5,069 & 5,047 & 3,380 & 3,056 & 60.5 & 1,991 & 39.5 \\
\hline 5. & Comarnic & 8,997 & 8,997 & 3,709 & 3,842 & 42.7 & 5,155 & 57.3 \\
\hline 6. & Aninoasa & 2,766 & 2,766 & 1,621 & 1,613 & 58.3 & 1,153 & 41.7 \\
\hline 7. & Bărbuleţu & 7,552 & 2,466 & 5,033 & 1,756 & 71.2 & 710 & 28.8 \\
\hline 8. & Bezdead & 5,757 & 5,757 & 3,237 & 3,237 & 56.2 & 2,520 & 43.8 \\
\hline 9. & Brăneşti & 4,303 & 1,795 & 1,715 & 878 & 48.9 & 917 & 51.1 \\
\hline 10. & Buciumeni & 2,871 & 2,871 & 1,899 & 1,899 & 66.1 & 972 & 33.9 \\
\hline 11. & Doiceşti & 1,098 & 1,098 & 643 & 648 & 59.0 & 450 & 41.0 \\
\hline 12. & Glodeni & 3,078 & 3,078 & 1,769 & 1,769 & 57.4 & 1,309 & 42.6 \\
\hline 13. & Gura Ocniţei & 4,496 & 4,496 & 2,250 & 2,174 & 48.3 & 2,322 & 51.7 \\
\hline 14. & Iedera & 5,341 & 5,341 & 1,021 & 1,021 & 19.1 & 4,320 & 80.9 \\
\hline 15. & Malu cu Flori & 2,271 & 2,271 & 1,533 & 1,533 & 67.5 & 738 & 32.5 \\
\hline 16. & Moroeni & 28,739 & 28,739 & 8,284 & 8,553 & 29.7 & 20,186 & 70.3 \\
\hline 17. & Moţăieni & 1,156 & 1,156 & 853 & 853 & 73.8 & 303 & 26.2 \\
\hline 17. & Ocniţa & 4,104 & 4,104 & 1,486 & 1,472 & 35.8 & 2,632 & 64.2 \\
\hline 19. & Pietrari & & 2,617 & $:$ & 1,652 & 63.1 & 965 & 36.9 \\
\hline 20. & Pietroşiţa & 2,707 & 2,707 & 1,102 & 1,102 & 40.7 & 1,605 & 59.3 \\
\hline 21. & Pucheni & 3,518 & 3,518 & 1,840 & 1,840 & 52.3 & 1,678 & 47.7 \\
\hline 22. & Râu Alb & : & 2,469 & $:$ & 1,627 & 65.9 & 842 & 34.1 \\
\hline 23. & Răzvad & 4,186 & 4,186 & 2,910 & 2,707 & 64.6 & 1,479 & 35.4 \\
\hline 24. & Runcu & 7,915 & 7,915 & 2,676 & 2,667 & 33.7 & 5,248 & 66.3 \\
\hline 25. & Şotânga & 3,515 & 3,515 & 1,411 & 1,273 & 36.2 & 2,242 & 63.8 \\
\hline 26. & Valea Lungă & 6,672 & 6,672 & 2,412 & 2,304 & 34.5 & 4,368 & 65.5 \\
\hline 27. & Vârfuri & 2,206 & 2,206 & 1,307 & 1,278 & 57.9 & 928 & 42.1 \\
\hline 28. & Vişineşti & 3,578 & 3,578 & 2,227 & 2,227 & 62.2 & 1,351 & 37.8 \\
\hline 29. & Voineşti & 8,103 & 8,103 & 3,361 & 3,361 & 41.5 & 4,742 & 58.5 \\
\hline 30. & Vulcana-Băi & 2,815 & 2,815 & 1,549 & 1,537 & 54.6 & 1,278 & 45.4 \\
\hline 31. & Vulcana-Pandele & : & 2,508 & $:$ & 825 & 32.9 & 1,683 & 67.1 \\
\hline 32. & Adunaţi & 2,270 & 2,270 & 1,358 & 1,489 & 65.6 & 781 & 34.4 \\
\hline 33. & Filipeştii de Pădure & 4,864 & 4,864 & 3,083 & 2,953 & 60.7 & 1,911 & 39.3 \\
\hline 34. & Măgureni & 4,801 & 4,814 & 2,142 & 1,876 & 38.9 & 2,938 & 61.1 \\
\hline 35. & Poiana Câmpina & 1,541 & 1,547 & : & 595 & 38.4 & 952 & 61.6 \\
\hline 36. & Proviţa de Jos & 2,528 & 2,530 & 1,255 & 1,217 & 48.1 & 1,313 & 51.9 \\
\hline 37. & Provița de Sus & 1,952 & 2,004 & 1,209 & 1,209 & 60.3 & 795 & 39.7 \\
\hline 38. & Talea & 2,485 & 2,485 & 1,594 & 1,518 & 61.1 & 967 & 38.9 \\
\hline \multirow[t]{2}{*}{39.} & Cetăţeni & 3,400 & 2,904 & 1,924 & 1,952 & 67.2 & 952 & 32.8 \\
\hline & TOTAL & 166,008 & 165,563 & 75,963 & 75,679 & 45.7 & 89,884 & 54.3 \\
\hline
\end{tabular}

Data source: processed data based on those provided by the National Statistics Institute, TEMPO-Online.

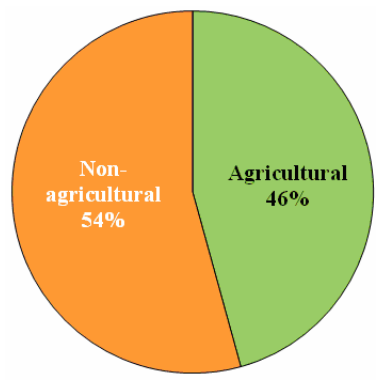

Fig. 4. Structure of the land fund area (\%), 2014.
Until about 150 years ago, local land use was dominated by forests, followed by grasslands and hay fields. At the end of the $19^{\text {th }}$ century, deforestation triggered the first land degradation. The development of the settlements and the growing number of inhabitants led to an extension of the agricultural areas (arable, grasslands and hay fields, then orchards), but also of the built areas.

The largest town by area is Comarnic, and the smallest is Fieni. In the case of the communes, the largest is Moroeni, and the smallest is Doiceşti. The 
ratio of agricultural to non-agricultural land brings to light extreme values for Iedera Commune, with 19.1\% agricultural area and $80.9 \%$ non-agricultural area, and, at the opposite side, for Moţăieni Commune, with
73.8\% agricultural land and just $26.2 \%$ non-agricultural land. The structure of the agricultural areas is presented in detail in Table 2 and presented synoptically in Figure 5 .

Table 2. Land fund - structure of the agricultural areas - 2014 (ha).

\begin{tabular}{|c|c|c|c|c|c|c|c|c|c|c|c|c|}
\hline No. & Town / Commune & Total & Arable & $(\%)$ & Pastures & $(\%)$ & $\begin{array}{c}\text { Hay } \\
\text { fields }\end{array}$ & $(\%)$ & $\begin{array}{c}\text { Vine } \\
\text { yards }\end{array}$ & $(\%)$ & Orchards & $(\%)$ \\
\hline 1. & Moreni & 957 & 148 & 15.5 & 389 & 40.6 & 404 & 42.2 & 1 & 0.1 & 15 & 1.6 \\
\hline 2. & Fieni & 1,062 & 71 & 6.7 & 461 & 43.4 & 500 & 47.1 & - & - & 30 & 2.8 \\
\hline & Pucioasa & 2,147 & 460 & 21.5 & 954 & 44.4 & 509 & 23.7 & - & - & 224 & 10.4 \\
\hline & Breaza & 3,056 & 94 & 3.1 & 594 & 19.4 & 2,031 & 66.5 & - & - & 337 & 11.0 \\
\hline & Comarnic & 3,842 & 79 & 1.9 & 1,640 & 42.6 & 1,735 & 45.5 & - & - & 388 & 10.0 \\
\hline & Aninoasa & 1,613 & 564 & 34.1 & 633 & 39.5 & 142 & 9.1 & - & - & 274 & 17.3 \\
\hline 7. & Bărbuleţu & 1,756 & 34 & 1.9 & 584 & 33.2 & 723 & 41.3 & - & - & 415 & 23.6 \\
\hline 8. & Bezdead & 3,237 & 216 & 6.7 & 1,376 & 42.5 & 1,270 & 39.2 & - & - & 375 & 11.6 \\
\hline & Brăneşti & 878 & 218 & 24.8 & 270 & 30.8 & 329 & 37.5 & 1 & 0.1 & 60 & 6.8 \\
\hline & Buciumeni & 1,899 & 30 & 1.6 & 902 & 47.5 & 615 & 32.4 & - & - & 352 & 18.5 \\
\hline & Doiceşti & 648 & 301 & 46.5 & 230 & 35.5 & 52 & 8.0 & 4 & 0.6 & 61 & 9.4 \\
\hline & Glodeni & 1,769 & 307 & 17.3 & 801 & 45.3 & 567 & 32.1 & 26 & 1.5 & 68 & 3.8 \\
\hline & Gura Ocniţei & 2,174 & 1,604 & 73.8 & 389 & 17.9 & 44 & 2.0 & 3 & 0.1 & 134 & 6.2 \\
\hline & Iedera & 1,021 & 323 & 31.6 & 461 & 45.2 & 156 & 15.3 & 2 & 0.2 & 79 & 7.7 \\
\hline & Malu cu Flori & 1,533 & 86 & 5.6 & 423 & 27.6 & 255 & 16.6 & - & - & 769 & 50.2 \\
\hline & Moroeni & 8,553 & 21 & 0.2 & 7,187 & 84.2 & 1,138 & 13.2 & - & - & 207 & 2.4 \\
\hline & Moţăieni & 853 & 36 & 4.2 & 249 & 29.2 & 533 & 62.5 & - & - & 35 & 4.1 \\
\hline 17. & Ocniţa & 1,472 & 479 & 32.5 & 777 & 52.8 & 190 & 12.9 & 10 & 0.7 & 16 & 1.1 \\
\hline & Pietrari & 1,652 & 116 & 7.0 & 694 & 42.0 & 580 & 35.1 & - & - & 262 & 15.9 \\
\hline & Pietroşiţa & 1,102 & 7 & 0.6 & 298 & 27.0 & 624 & 56.7 & - & - & 173 & 15.7 \\
\hline & Pucheni & 1,840 & 47 & 2.6 & 570 & 31.0 & 952 & 51.7 & - & - & 271 & 14.7 \\
\hline & Râu Alb & 1,627 & 31 & 1.9 & 688 & 42.3 & 578 & 35.5 & - & - & 330 & 20.3 \\
\hline 23. & Răzvad & 2,707 & 1,539 & 56.9 & 739 & 27.3 & 360 & 13.3 & 33 & 1.2 & 36 & 1.3 \\
\hline & Runcu & 2,667 & 48 & 1.8 & 1,326 & 49.8 & 1,069 & 40.0 & - & - & 224 & 8.4 \\
\hline & Şotânga & 1,273 & 667 & 52.4 & 303 & 23.8 & 270 & 21.3 & 3 & 0.2 & 30 & 2.3 \\
\hline 26. & Valea Lungă & 2,304 & 330 & 14.3 & 1,094 & 47.5 & 873 & 37.9 & - & - & 7 & 0.3 \\
\hline & Vîrfuri & 1,278 & 74 & 5.8 & 411 & 32.1 & 626 & 49.1 & - & - & 167 & 13.0 \\
\hline 28. & Vişineşti & 2,227 & 101 & 4.5 & 516 & 23.2 & 1,486 & 66.7 & - & - & 124 & 5.6 \\
\hline 29. & Voineşti & 3,361 & 678 & 20.2 & 930 & 27.7 & 453 & 13.5 & - & - & 1,300 & 38.6 \\
\hline 30. & Vulcana-Băi & 1,537 & 101 & 6.6 & 270 & 17.6 & 1,153 & 75.0 & - & - & 13 & 0.8 \\
\hline 31. & Vulcana-Pandele & 825 & 262 & 31.6 & 312 & 37.9 & 241 & 29.3 & - & - & 10 & 1.2 \\
\hline 32. & Adunaţi & 1,489 & 49 & 3.3 & 461 & 31.0 & 805 & 54.0 & - & - & 174 & 11.7 \\
\hline 33. & Filipeştii de Pădure & 2,953 & 1,674 & 56.7 & 759 & 25.8 & 342 & 11.7 & 5 & 0.2 & 173 & 5.6 \\
\hline 34. & Măgureni & 1,876 & 1,031 & 55.0 & 605 & 32.2 & 120 & 6.4 & - & - & 120 & 6.4 \\
\hline 35. & Poiana Câmpina & 595 & 70 & 11.8 & 278 & 46.7 & 148 & 24.9 & - & - & 99 & 16.6 \\
\hline 36. & Proviţa de Jos & 1,217 & 124 & 10.2 & 304 & 25.0 & 724 & 59.5 & - & - & 65 & 5.3 \\
\hline 37. & Proviţa de Sus & 1,209 & 75 & 6.2 & 506 & 41.8 & 496 & 41.1 & - & - & 132 & 10.9 \\
\hline & Talea & 1,518 & 46 & 3.0 & 686 & 45.2 & 645 & 42.5 & - & - & 141 & 9.3 \\
\hline & Cetăţeni & 1,952 & 65 & 3.3 & 471 & 24.1 & 960 & 49.2 & - & - & 456 & 23.4 \\
\hline & TOTAL & 75,679 & 12,206 & 16.1 & 30,541 & 40.4 & 24,698 & 32.6 & 88 & 0.1 & 8.146 & 10.8 \\
\hline
\end{tabular}

Data source: processed data based on those provided by the National Statistics Institute, TEMPO-Online.

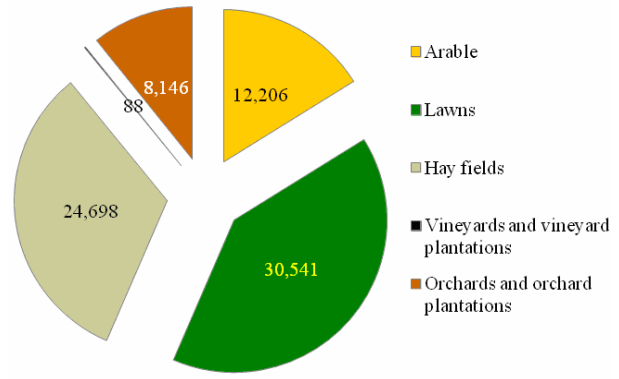

Fig. 5. Structure of the agricultural area (ha), 2014.
Thus, one can note that arable lands represent just $16.1 \%$ of the total (corn, wheat, rye, barley, two-row barley), met often in the large depressions. On the other hand, grasslands and hayfields record the highest ratios $-40.45 \%$ and $32.6 \%$ (covering large areas on the slopes or in the secondary valleys).

Orchards (mainly apple trees and plum trees) cover $10.2 \%$ of the land and vineyards are very few (0.1\%). For a Subcarpathian area these values are considered, overall, normal. The largest proportion of 
arable land belongs to Gura Ocniței Commune, the highest grasslands ratio appears in Moroeni, and the highest hayfields ratio is recorded in Vulcana Băi. Orchards record the highest ratio in Malu cu Flori, and vineyards in Glodeni (there are vineyards only in 10 out of the 34 communes and 5 towns) (see Table 2). Orchards are characteristic of the economic profile, especially in the communes of Dâmboviţa County (26 $\mathrm{kg}$ of fruit/inhabitant compared to $13 \mathrm{~kg}$ of fruit/inhabitant in Prahova County). The 89,884 ha of non-agricultural lands are $85.6 \%$ forests, which, economically, constitute a positive, favourable element (Table 3 \& Fig. 6).

Table 3. Land fund - structure of the non-agricultural area - 2014 (ha).

\begin{tabular}{|c|c|c|c|c|c|c|c|c|c|c|c|c|}
\hline No. & Town / Commune & Total & Forests & $\%$ & $\begin{array}{c}\text { Waters } \\
\& \\
\text { marshes }\end{array}$ & $(\%)$ & $\begin{array}{l}\text { Cons- } \\
\text { tructions }\end{array}$ & $(\%)$ & $\begin{array}{c}\text { Ways of } \\
\text { communi- } \\
\text { cation }\end{array}$ & $(\%)$ & $\begin{array}{l}\text { Degraded } \\
\& \\
\text { unproduc- } \\
\text { tive }\end{array}$ & $(\%)$ \\
\hline 1. & Moreni & 2,557 & 1,897 & 74.2 & 48 & 1.9 & 490 & 19.2 & 97 & 3.7 & 25 & 1.0 \\
\hline 2. & Fieni & 769 & 524 & 69.1 & 76 & 9.4 & 127 & 16.5 & 42 & 5.0 & - & - \\
\hline 3. & Pucioasa & 1,862 & 1,374 & 73.9 & 111 & 5.8 & 253 & 13.7 & 100 & 5.2 & 24 & 1.4 \\
\hline 4. & Breaza & 1,991 & 1,074 & 53.9 & 143 & 7.2 & 432 & 21.7 & 190 & 9.6 & 152 & 7.6 \\
\hline 5. & Comarnic & 5,155 & 4,637 & 89.9 & 70 & 1.4 & 245 & 4.7 & 122 & 2.4 & 81 & 1.6 \\
\hline 6. & Aninoasa & 1,153 & 731 & 63.4 & 38 & 3.3 & 276 & 24.0 & 88 & 7.6 & 20 & 1.7 \\
\hline 7. & Bărbuleţu & 710 & 539 & 76.0 & 29 & 4.1 & 54 & 7.6 & 43 & 6.0 & 45 & 6.3 \\
\hline 8. & Bezdead & 2,520 & 2,235 & 88.7 & 132 & 5.2 & 88 & 3.6 & 49 & 1.9 & 16 & 0.6 \\
\hline 9. & Brăneşti & 917 & 693 & 75.6 & 57 & 6.2 & 110 & 12.0 & 36 & 3.9 & 21 & 2.3 \\
\hline 10. & Buciumeni & 972 & 674 & 69.3 & 99 & 10.2 & 80 & 8.2 & 59 & 6.1 & 60 & 6.2 \\
\hline 11. & Doiceşti & 450 & 111 & 24.7 & 47 & 10.4 & 199 & 44.2 & 88 & 19.6 & 5 & 1.1 \\
\hline 12. & Glodeni & 1,309 & 1,127 & 86.1 & 17 & 1.3 & 79 & 6.0 & 73 & 5.6 & 13 & 1.0 \\
\hline 13. & Gura Ocniţei & 2,322 & 1,753 & 75.5 & 111 & 4.8 & 344 & 14.8 & 96 & 3.7 & 18 & 0.8 \\
\hline 14. & Iedera & 4,320 & 4,115 & 95.3 & 83 & 1.9 & 66 & 1.5 & 45 & 1.0 & 11 & 0.3 \\
\hline 15. & Malu cu Flori & 738 & 415 & 56.2 & 70 & 9.5 & 155 & 21.0 & 48 & 6.5 & 50 & 6.8 \\
\hline 16. & Moroeni & 20,186 & 18,921 & 93.7 & 235 & 1.2 & 118 & 0.6 & 109 & 0.5 & 803 & 4.0 \\
\hline 17. & Moţăieni & 303 & 177 & 58.4 & 58 & 19.1 & 41 & 13.6 & 26 & 8.6 & 1 & 0.3 \\
\hline 17. & Ocniţa & 2,632 & 2,458 & 93.4 & 23 & 0.9 & 91 & 3.5 & 54 & 2.0 & 6 & 0.2 \\
\hline 19. & Pietrari & 965 & 827 & 85.7 & 35 & 3.7 & 53 & 5.5 & 42 & 4.3 & 8 & 0.8 \\
\hline 20. & Pietroşiţa & 1,605 & 1,461 & 91.0 & 23 & 1.4 & 61 & 3.8 & 38 & 2.4 & 22 & 1.4 \\
\hline 21. & Pucheni & 1,678 & 1,516 & 90.3 & 27 & 1.6 & 42 & 2.5 & 66 & 3.9 & 27 & 1.6 \\
\hline 22. & Râu Alb & 842 & 723 & 85.4 & 42 & 5.0 & 35 & 4.2 & 35 & 4.6 & 7 & 0.8 \\
\hline 23. & Răzvad & 1,479 & 1,011 & 68.4 & 80 & 5.4 & 266 & 18.0 & 121 & 8.1 & 1 & 0.1 \\
\hline 24. & Runcu & 5,248 & 4,954 & 94.4 & 91 & 1.7 & 77 & 1.5 & 71 & 1.4 & 55 & 1.0 \\
\hline 25. & Şotânga & 2,242 & 1,806 & 80.5 & 80 & 3.6 & 116 & 5.2 & 66 & 2.9 & 174 & 7.8 \\
\hline 26. & Valea Lungă & 4,368 & 4,032 & 92.3 & 78 & 1.8 & 172 & 3.9 & 83 & 1.9 & 3 & 0.1 \\
\hline 27. & Vîrfuri & 928 & 784 & 84.5 & 9 & 1.0 & 92 & 9.9 & 34 & 3.6 & 9 & 1.0 \\
\hline 28. & Vişineşti & 1,351 & 1,192 & 88.3 & 20 & 1.5 & 81 & 6.0 & 55 & 4.0 & 3 & 0.2 \\
\hline 29. & Voineşti & 4,742 & 4,362 & 91.7 & 124 & 2.8 & 119 & 2.5 & 118 & 2.5 & 19 & 0.5 \\
\hline 30. & Vulcana-Băi & 1,278 & 1,115 & 87.2 & 13 & 1.0 & 60 & 4.7 & 70 & 5.5 & 20 & 1.6 \\
\hline 31. & Vulcana-Pandele & 1,683 & 1,491 & 88.5 & 70 & 4.2 & 64 & 3.8 & 38 & 2.3 & 20 & 1.2 \\
\hline 32. & Adunaţi & 781 & 671 & 86.0 & 32 & 4.1 & 51 & 6.5 & 27 & 3.4 & - & - \\
\hline 33. & Filipeştii de Pădure & 1,911 & 1,331 & 69.6 & 78 & 4.1 & 349 & 18.3 & 133 & 7.0 & 20 & 1.0 \\
\hline 34. & Măgureni & 2,938 & 2,141 & 72.9 & 19 & 0.6 & 431 & 14.7 & 49 & 1.7 & 298 & 10.1 \\
\hline 35. & Poiana Câmpina & 952 & 650 & 68.3 & 78 & 8.2 & 163 & 17.1 & 44 & 4.6 & 17 & 1.8 \\
\hline 36. & Proviţa de Jos & 1,313 & 1,162 & 88.6 & 40 & 3.0 & 57 & 4.3 & 40 & 3.0 & 14 & 1.1 \\
\hline 37. & Proviţa de Sus & 795 & 603 & 75.9 & 36 & 4.5 & 110 & 13.8 & 32 & 4.0 & 14 & 1.8 \\
\hline 38. & Talea & 967 & 887 & 91.7 & - & - & 28 & 2.9 & - & - & 52 & 5.4 \\
\hline \multirow[t]{2}{*}{39.} & Cetăţeni & 952 & 815 & 85.6 & - & - & 43 & 4.6 & 47 & 4.9 & 47 & 4.9 \\
\hline & TOTAL & 89,884 & 76,989 & 85.6 & 2,422 & 2.7 & 5.718 & 6.4 & 2,574 & 2.9 & 2,181 & 2.4 \\
\hline
\end{tabular}

Data source: processed data based on those provided by the National Statistics Institute, TEMPO-Online.

For the northern half of the area, the forest has been an element bringing unity, uniformity [4]. Constructions represent $6.4 \%$ of the total nonagricultural areas, while the remaining categories ways of communication, waters and marshes, degraded and unproductive lands - exist in similar proportions, i.e. between 2.4 and $2.9 \%$. On the level of the administrative territorial units, forests record the highest ratio in Iedera Commune (95.3\%) and the lowest in Doiceşti Commune (24.7\%). On the other hand, Doiceşti 
is the commune with the highest ratio of built-up areas (44.2\%), a fact decisively influenced by the presence of the well-known power station.

The lowest ratio of built-up areas is recorded by Moroeni Commune (o.6\%), the explanation being that although this is the largest commune, most of it is situated in the alpine area. Doiceşti Commune holds the first position as well for the ratio of the area covered by communication infrastructure (19.6\%), at the opposite end being once again Moroeni Commune (the explanation is the same as for the previous situation). The largest ratio of degraded lands is recorded by Măgureni Commune, and the lowest by Răzvad and Valea Lungă.

Table 4. Real property area.

\begin{tabular}{|c|c|}
\hline Town/ Commune & $\begin{array}{l}\text { Area occupied with } \\
\text { constructions (ha) }\end{array}$ \\
\hline 1. Moreni & 610.00 \\
\hline 2. Fieni & 539.00 \\
\hline 3. Pucioasa & 940.00 \\
\hline 4. Breaza & $2,167.00$ \\
\hline 5. Comarnic & $1,729.00$ \\
\hline 6. Aninoasa & 539.86 \\
\hline 7. Bărbuleţu & 275.00 \\
\hline 8. Bezdead & 468.00 \\
\hline 9. Brăneşti & 266.23 \\
\hline 10. Buciumeni & 278.52 \\
\hline 11. Doiceşti & 199.00 \\
\hline 12. Glodeni & 356.54 \\
\hline 13. Gura Ocniţei & 568.00 \\
\hline 14. Iedera & 221.20 \\
\hline 15. Malu cu Flori & 550.63 \\
\hline 16. Moroeni & 660.00 \\
\hline 17. Moțăieni & 286.00 \\
\hline 18. Ocniţa & 470.00 \\
\hline 19. Pietrari & 289.00 \\
\hline 20. Pietroşiţa & 260.00 \\
\hline 21. Pucheni & 378.00 \\
\hline 22. Râu Alb & 256.00 \\
\hline 23. Răzvad & $1,258.00$ \\
\hline 24. Runcu & 860.00 \\
\hline 25. Şotânga & 465.31 \\
\hline 26. Valea Lungă & 670.00 \\
\hline 27. Vîrfuri & 376.00 \\
\hline 28. Vişineşti & 392.00 \\
\hline 29. Voineşti & $1,100.00$ \\
\hline 30. Vulcana-Băi & 420.00 \\
\hline 31. Vulcana-Pandele & 250.40 \\
\hline 32. Adunaţi & 490.52 \\
\hline 33. Filipeştii de Pădure & 689.47 \\
\hline 34. Măgureni & 500.00 \\
\hline 35. Poiana Câmpina & 473.50 \\
\hline 36. Proviţa de Jos & 356.20 \\
\hline 37. Proviţa de Sus & 444.61 \\
\hline 38. Talea & 285.00 \\
\hline 39. Cetăţeni & 360.00 \\
\hline TOTAL & $21,697.99$ \\
\hline
\end{tabular}

Beside the agricultural settlements, there are also many rural agro-industrial settlements (oil exploitation activities: Aninoasa, Gura Ocniţei etc.; coal mining: Filipeştii de Pădure, Şotânga; spa resources: Vulcana Băi; construction materials, salt etc.).

The real property area of all the settlements in the zone under analysis is 21,697.99 ha, representing $13.1 \%$ of the total. From this perspective, on the first place is situated, for the towns, Breaza, and on the last, Fieni, while among the communes, on the first position is Răzvad, and on the last, Doiceşti (Table 4).
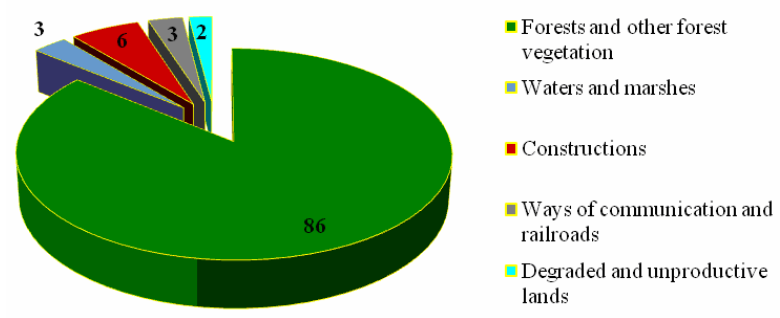

Fig. 6. Structure of the non-agricultural area (ha),

\subsection{Dispersion index}

The rural settlements' dispersion index offers the possibility of analyzing: the evolution of the village hearths in various types of areas; features resulted from their habitat energy; and architectural evolutions in the built areas. It is a tool giving the possibility to make quantitative and qualitative assessments on the settlements particularities and on the respective communities' structure [10].

The dispersion index was calculated on the commune level by using A. Demangeon's formula [26]:

$$
U=\frac{\left(N-\mathrm{N}^{\prime}\right) n}{N}
$$

where:

$$
\begin{aligned}
& U \text {-dispersion index; } \\
& N \text { - total number of inhabitants; } \\
& \mathrm{N}^{\prime} \text { - number of inhabitants in residential area; } \\
& n-\text { number of villages that are not }
\end{aligned}
$$
administrative centre.

Out of the 34 communes, 11 (32.35\%) record a small dispersion index, with values between 0 and 0.5 here there are also five cases recording the value "o" because either the respective communes have a single village included (Doiceşti and Ocniţa), or a single village of the respective commune lies strictly within the area under analysis (Gura Ocniţei, Răzvad and Măgureni). Values between 0.51 and 1.00 appear in three cases (8.82\%). To the interval $1.01-1.50$ belong nine communes (26.47\%), between 1.51 and 2.00 are four (11.78\%), between 2.01 and 5.00, six (17.64\%), and over 5.01, just one 2.94\% - Valea Lungă (Fig. 7). 


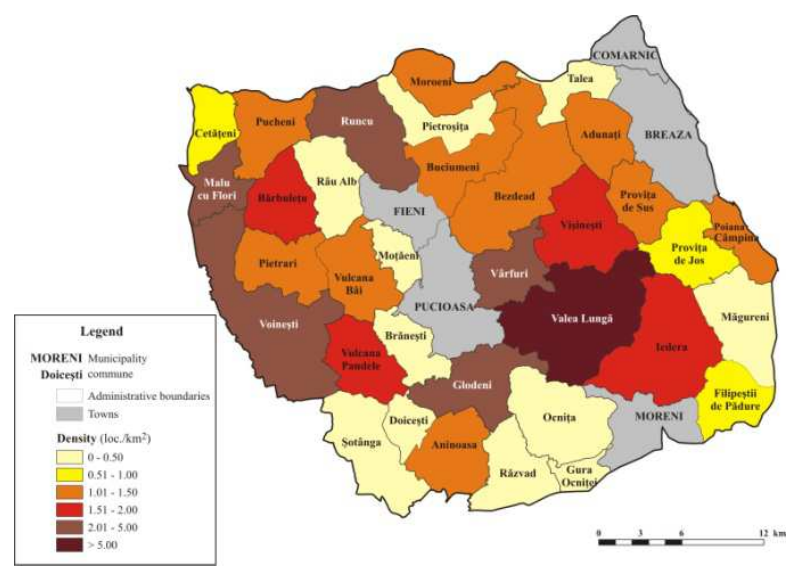

Fig. 7. Rural settlements dispersion index.

\subsection{Habitation quality features and indicators}

The habitation features highlight very well aspects concerning the quality of life. The habitation indicators dynamics also suggest the economic, social or cultural dynamics.

The human population existence is founded on habitation conditions [27], habitation being a complex process that supposes a permanent correlation between the natural and the anthropogenic environment. It is a defining human development element. At the same time, habitation is the result of the combination between economic, social, historical and political conditions, processes and phenomena. Other factors that can influence the habitation quality are administrative, legislative, and the behavioural framework of the human society in different historical stages. Habitation quality is, firstly, the basic dimension of the quality of life [28].

The number of dwellings during the period under analysis (1990 - 2015) had an approximately constant evolution, except for the period 2000 - 2005 when the increase was double compared to the other intervals under analysis (Fig. 8), corresponding to the so-called real estate "boom" on the national level (which lasted until the year 2007).

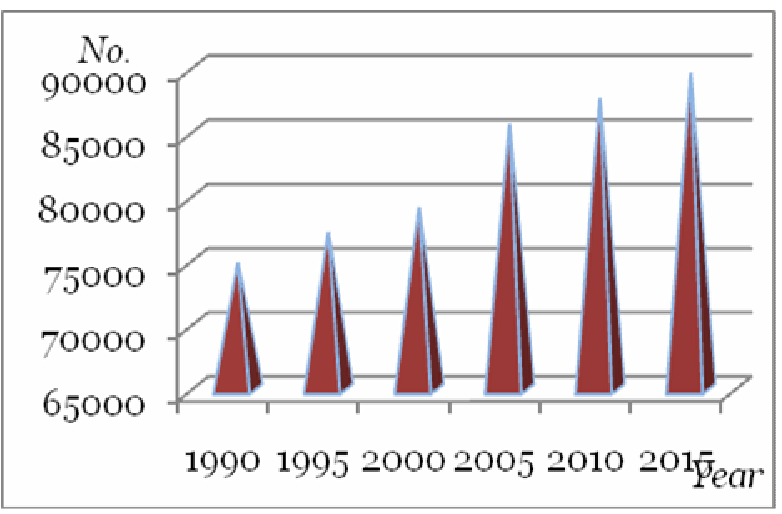

Fig. 8. Evolution of the number of dwellings (19902015).
In absolute figures, the number of dwellings increased in the entire area of the Ialomiţa Subcarpathians from 74,894 in the year 1990 to 89,666 in the year 2015, i.e. an increase of $19.7 \%$. The increase is greater in the urban area (23\%) compared to the rural area $(18.1 \%)$. The town with the greatest increase is Breaza $-41 \%$, and for the rural area the maximal increase ratio is recorded in Vulcana Băi - 40.5\%. At the same time, growths of over $30 \%$ were also recorded in Poiana Câmpina (35.5\%), Pietroşiţa (35\%), Ocniţa (34.6\%) and Moroeni (33.1\%). One can note that these values, much higher than the average, appear in localities whose common points are: favourable climatic conditions that also determined the development of tourist activities, and good accessibility, considerations that triggered the construction of secondary residences or holiday homes by the inhabitants of large cities situated nearby (Bucharest, Ploieşti, Târgovişte). These can be considered attractive areas, and, at the opposite pole, where low increases have been recorded, under 5.0\%, we find the communes Vişineşti (5.0\%), Glodeni (4.5\%), Doiceşti (4.4\%), Malu cu Flori (3.3\%), Pucheni (1.4\%) and Talea (0.9\%); there is a single case of decrease in the number of dwellings - Vârfuri Commune (- 0.2\%) - all these can be considered restrictive areas, in most situations the main cause being the low accessibility.

The number of inhabitants / dwelling represents a synoptic indicator highlighting the quality of life under several aspects. The result is a decrease of this number (Fig. 9), from 3.07 in the year 1990 to 2.38 in the year 2015, a value under the average of about 2.7 inhabitants/dwelling recorded on the national level, which is a positive aspect from the perspective of comfort, yet reflecting some negative aspects, such as the demographic ageing in the rural area or the general demographic decrease caused mainly by a decreasing birth rate and by external migration.

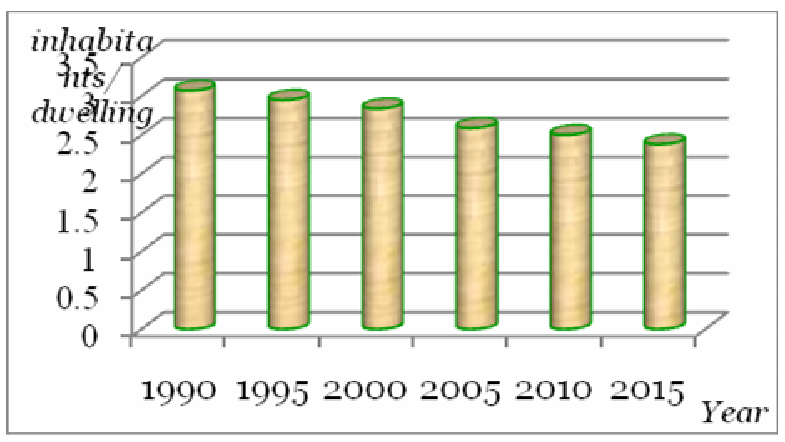

Fig. 9. No. of inhabitants/dwelling (1990-2015)

The average size of a dwelling has grown constantly, especially during the last part of the period under analysis, i.e. after the year 2010 (Fig. 10). The average size of dwelling has grown from $29.6 \mathrm{~m}^{2}$ in 1990 to $48.74 \mathrm{~m}^{2}$ in 2015 , i.e. a substantial growth, of 
64.6\%. The main explanation is that mostly individual buildings have been built, generally on two floors, whereas the construction of apartments in towns decreased significantly (in some cases, no constructions at all have been recorded).

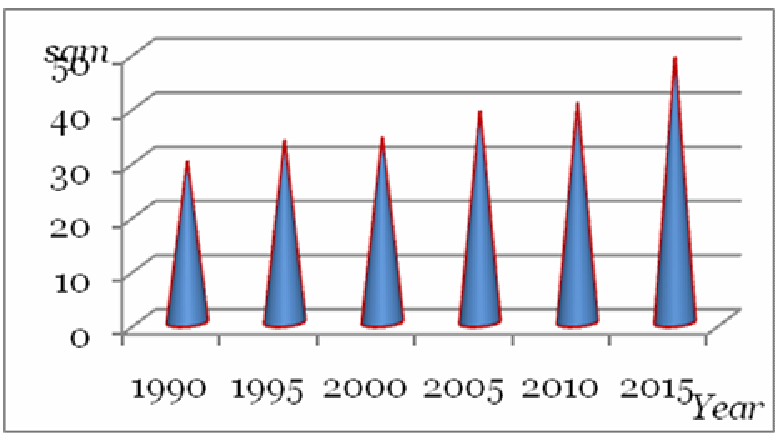

Fig. 10. Average dwelling area evolution (1990-2015).

The average dwelling area / inhabitant is closely related to the previous aspect, recording a constant and continual growth, especially during the periods $2000-2005$ and $2010-2015$ (Fig. 11). The growth during the whole interval was $95.6 \%$ (it almost doubled, from $9.63 \mathrm{~m}^{2}$ per inhabitant in 1990 to 18.84 $\mathrm{m}^{2}$ /inhabitant in 2015). The growth "sources" were practically two - on the one hand the increase of the average dwelling area (presented previously), and on the other hand the decrease of the number of inhabitants.

The present values are slightly under the national average and significantly under the European norms (about $50 \%$ of their value). And, although the 1990 level of this indicator was very low, the growth remains remarkable.

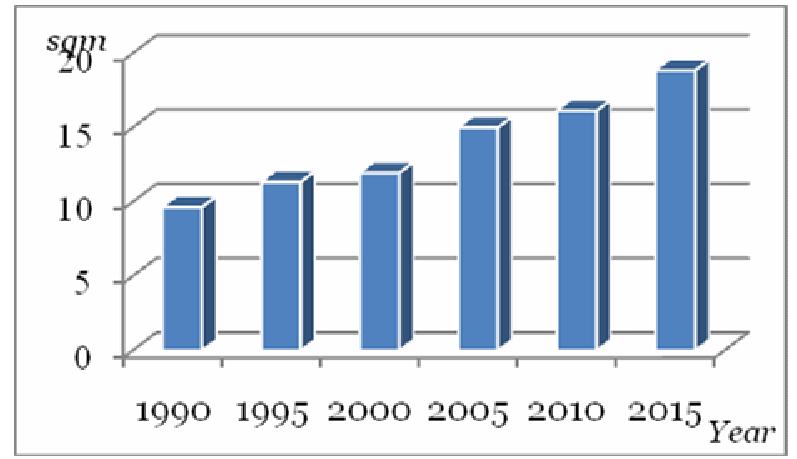

2015).

Fig. 11. Average dwelling area/Inhabitant (1990-

The dynamics of the number of construction permits (residential buildings), for the interval 20022015, shows (according to the statistical data available) a clear increase until the year 2007 (from 611 to 796) followed by a sharp decrease with the onset of the economic crisis in the year 2008 (Fig. 12), down to a level below the one of the year 2002 (419).

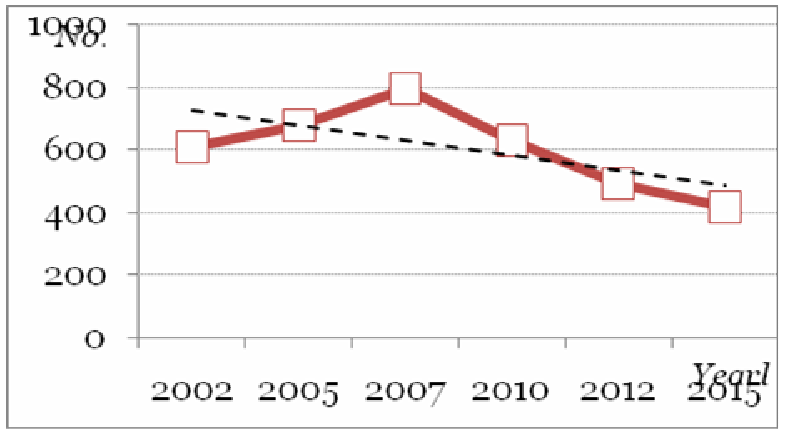

Fig. 12. Dynamics of the number of construction permits (residential buildings) 2002-2015.

The dynamics of the average area of the newly-built residential buildings - indicates an increase (Fig. 13), from $113.73 \mathrm{~m}^{2}$ (2002) to $144.79 \mathrm{~m}^{2}$ (2015), i.e. 27.3\%. Thus, it results that larger houses are built - just the average number of inhabitants / dwelling would show values almost double compared to the European norms regarding the average dwelling area per inhabitant.

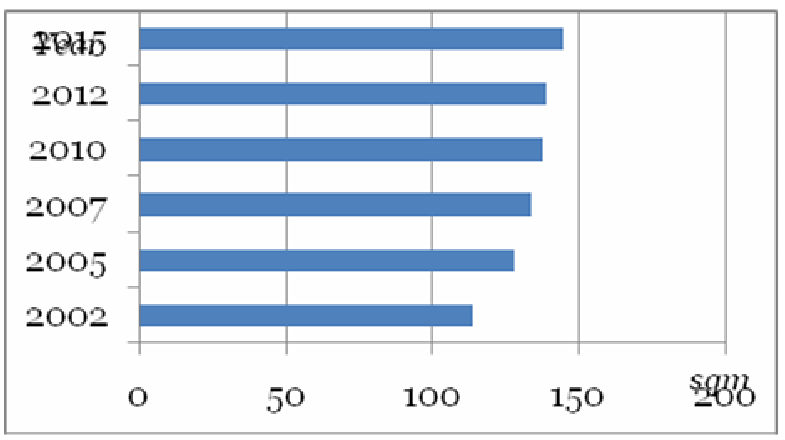

Fig. 13. Dynamics of the average area newly-built residential buildings (2002-2015).

The dynamics of the total area of newly-built residential constructions (Fig. 14) highlights a negative trend after the emergence of the economic crisis; however, one can note a reduction of the rate of decrease after the year 2012. This aspect can be explained by the decrease of the number of newly-built dwellings - meaning that fewer, yet larger dwellings are built, which leads to a growing gap in the standard of living.

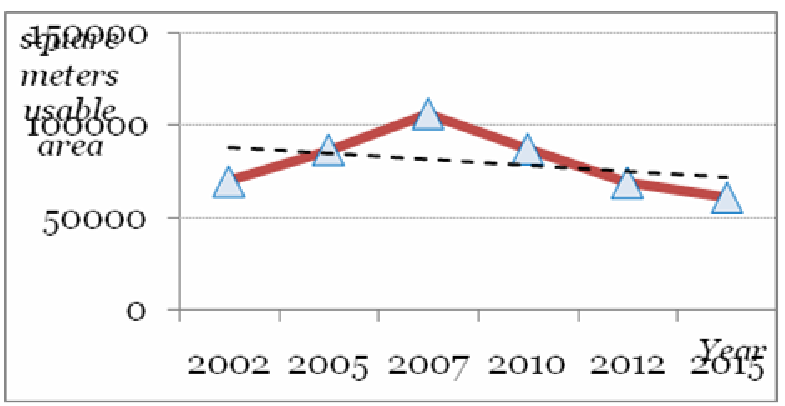

Fig. 14. Dynamics of the total area of newly-built residential constructions (2002-2015). 
Between 2002 and 2007 the total area of newly-built residential constructions increased by 53.1\%, whereas between 2007 and 2015 the decrease was of $75.4 \%$. if we compare 2015 to 2002 the decrease in the total useful area of the newly-built residential buildings is of $14.5 \%$.

\section{CONCLUSION}

The population and human settlements density highlights a populous area, with a high density of settlements. One can note a slight dominance of the non-agricultural lands in the land fund structure. The largest areas are covered by forests, grasslands and hay fields, these giving the key note of the landscape. In the communes where habitation quality is higher the forests ratio is very high, the grazing fields and hayfields are over the average and the degraded land ratio is over the average of the area.

Thus, the dispersion index records small and average values for about $60 \%$ of the settlements. This index is correlated with the habitation quality as follows: where it is low (between 0.5 and 1.5) the habitation quality is higher.

Viewed through the prism of the first two habitation quality indicators, a positive dynamics has been recorded, i.e. a decrease of the average number of persons per dwelling (while the number of dwellings has increased), but also a decrease in the number of inhabitants. At the same time, significant growths appear as well in the case of the average area of a dwelling, and of the average dwelling area per inhabitant.

The year 2008, which marked the beginning of the economic crisis, is also well highlighted in the decrease of the number of dwellings built, the trend continuing to be negative to this day. On the other hand, the newly built constructions are increasingly larger.

The analysis of the social and economic aspects denotes, however, the existence of a quite excessive economic polarization, significant differences among communes or even among villages within one and the same commune, aspects that can determine migrations (outside or even inside the area). The dynamics of the values and indicators analyzed for habitation quality delimits attractive and less attractive zones in this area, not totally overlapping the above-mentioned economic polarization. The common elements are related to the development of tourist activities (economically) and of the accessibility (from the perspective of natural conditions).

On the other hand, although the area offers rich and varied resources, the field research highlighted that the development potential of the Ialomiţa Subcarpathians is restricted in the actions of use, organization and optimization of the area because great 46 difficulties are met due to the land degradation processes, which are generalized in the area. These processes are very diverse genetically and morphologically [2]. Land fund improvement works, forest fund conservation and restoration works, water course arrangement works (even for the small waters) are needed. On the whole, actions meant to protect the environment and organize/systematize the area are needed. All these would alleviate the restrictive factors and would increase the attractiveness potential of this area, first of all for its inhabitants (in the attempt of making them stay here instead of leaving for other places in Romania or abroad), and second for the potential inhabitants or investors. This is possible because the indicators under analysis denote positive aspects.

An efficient and pro-active management can profitably use the strengths of the area despite the apparent paradox: area with demographic and economic decrease, yet with overall increase of the habitation quality and implicitly life quality via the aspects under analysis. In this regard, a number of weaknesses, such as the demographic and economic decline (especially industrial) could be turned into strengths, starting from the present situation, which highlights, at least on the theoretical and statistical level, favourable habitation quality aspects, which can have positive influences on the quality of life in general. Practically, a functional restructuring could be considered - the decrease of the secondary sector activities can be compensated by the increase of those of the tertiary sector, with obvious benefits also for the environmental elements, all while the keeping, improved efficiency and diversification of the primary sector activities, singling out the area.

\section{REFERENCES}

[1] Antohe, Carmen (2003), Unele consideraţii cu privire la raporturile dintre aşezări şi relief în Subcarpaţii dintre Dâmboviţa şi Ialomiţa. [Some considerations on the relations between settlements and relief in the Subcarpathians in between Dambovita and Ialomita], In: Analele Universităţii "Valahia" Târgovişte, Seria Geografie, Tom 3, Romania, pp. 255260.

[2] Loghin, V. (2013), Studii, comunicări, articole. [Studies, Communications, Articles], Editura Cetatea de Scaun, Târgovişte, Romania.

[3] Conea, I. (1931), Aşezările omeneşti în depresiunea subcarpatică din Oltenia. [Human settlements in the Subcarpathian depression of Oltenia], In: Buletinul Societăţii Regale Române de Geografie, Tom. L, Atelierele Grafice SOCEC \& Co., Bucureşti, Romania.

[4] Dumitrescu, Daniela (2008), Habitatul rural din Piemontul Cândeşti. [The Rural Habitat of Candesti 
Piedmont], Editura Cetatea de Scaun, Târgovişte, Romania.

[5] Popp, N. (1939), Subcarpaţii dintre Dâmboviţa şi Prahova. Studiu geomorfologic. [The Subcarpathians in-between Dambovita and Prahova. Geomorphological Study], Societatea Regală Română de Geografie, Romania.

[6] Velcea, Valeria (2001), Geografia fizică a României. [Physical Geography of Romania], Editura Universităţii “Lucian Blaga”, Sibiu, Romania.

[7] Corpade, Ana-Maria (2011), Mediul real, mediul perceput şi comportament uman în Depresiunea Maramureşului - rezumatul tezei de doctorat. [Real Environment, Perceived Environment and Human Behavior in Maramures Depression - doctoral thesis abstract], Facultatea de Geografie, Universitatea BabeşBolyai Cluj Napoca, România.

[8] Popescu, Claudia (1999), Relaţii între activităţile industriale şi organizarea spaţiului geografic. [Relations between the Industrial Activities and the Organization of the Geographic Area], Teză de doctorat.

[9] Cândea, Melinda, Bran, Florina (2001), Spațiul geografic românesc. Organizare, amenajare, dezvoltare. [The Romanian Geographic Area. Organization, Arrangement, Development], Editura Economică, Bucureşti, Romania.

[10] Baltalungă, A. A. (2008), Geografia aşezărilor. [Geography of Settlements], Editura Cetatea de Scaun, Târgovişte, Romania.

[11] Cândea, Melinda, Bogan, Elena, Simon, Tamara (2011), Așezările umane și organizarea spațiului geografic. [Human Settlements and Organization of the Geographic Area], Editura Universitară, București, Romania, apud Vidal de la Blache, P. (1922), Principes de Geographie humaine. [Principles of Human Geography], Librairie Armánd Colin, Paris, France.

[12] Maslow, A. H. (1970), Motivation and Personality, $2^{\text {nd }}$ ed., New York, Harper \& Row, USA.

[13] Bogan, R. (2011), Dinamica actuală a proceselor şi fenomenelor sociale din Depresiunea Zlatna rezumatul tezei de doctorat. [The Present Dynamics of the Social Processes and Phenomena of Zlatna Depression], Universitatea din Bucureşti, Romania.

[14] Bailly, A. et al. (1995). Les concepts de la géographie humaine, $3^{o}$ edition. [The Concepts of Human Geography], Masson, Paris. France.

[15] Erdeli, G. et. al. (1999), Dicţionar de geografie umană. [Dictionary of Human Geography], Editura Corint, Bucureşti, Romania, p.182.

[16] Zotic, V., Alexandru, Diana-Elena, Puiu, V. (2010), Functional Zoning of the City/Village Area and Its Contribution to the Sustainable Development of Settlements In: Journal of Settlements and Spatial Planning, vol. 1, no. 2, Romania, pp. 181-189.

[17] Nae, Mirela (2006), Geografia calităţii vieţii urbane - metode de analiză. [The Geography of Urban
Life Quality - Analysis Methods], Editura Universitară, , Bucureşti, Romania.

[18] Manolache, C. I. (2017), Calitatea locuirii în Judeţul Vaslui. [Quality of life in Vaslui County], Editura Pim, Iaşi, Romania.

[19] Uehara, E. S. (1994), Journ al of Health and Social Behavior. 35(4): 312.

[20] Lawrence, R. (1995), Housing quality: an agenda for research, Urban Studies 32(10): 1655-1664.

[21] Castro, M. E. (1999), Habitabilidad, medio ambiente y ciudad. [Habitability, environment and city], In: $2^{\circ}$ Congreso Latinoamericano: El habitar, una orientación para la investigación proyectual. Universidad Autónoma Metropolitana, México.

[22] *** (2016), National Statistics Institute. TEMPOOnline Time series. Available at: http://statistici.insse. ro/shop/?page=info

[23] *** (2016), Direcţia Judeţeană de Statistică Dâmboviţa. Statistici judeţene. [Departament of Statistics, Dambovita County. County statistics.]. Available at: http://www.dambovita.insse.ro/main.php [24] *** (2016), Direcţia Judeţeană de Statistică Prahova. Statistici judeţene. [Department of Statistics, Prahova County. County statistics.]. Available at: http://www.prahova.insse.ro/main.php

[25] *** (2016), Direcţia Judeţeană de Statistică Argeş. Statistici judeţene. [Departament of Statistics, Arges County. County statistics.]. Available at: http://www.arges.insse.ro/main.php

[26] Cucu, V. (1981), Geografia populaţiei şi aşezărilor umane. [Population Geography and Human Settlements], Editura Didactică şi Pedagogică, Bucureşti, Romania.

[27] Alpopi, Cristina (2008), Locuirea urbană. [Urban Habitation], In: Cercetări practice şi teoretice în Managementul Urban, anul 3, nr. 8.

[28] Trudel, J. (1989), Nouvelles approches concernant l'évaluation de la qualité de l'habitat. [New approach to assessing the quality of habitat], Rapport d'étude et document de consultation, Ed. de Société d'habitation du Quebec, p. 9. 